\title{
Barakong: Cultural Sufism in the A'burangga Tradition to the Bantaeng Kings' Descendant
}

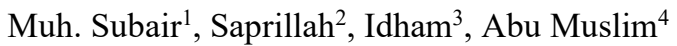 \\ \{ingatbair@gmail.com¹, pepilitbang@gmail.com², idbodi@yahoo.co.id ${ }^{3}$, \\ abumuslim.litbang@gmail.com $\left.{ }^{4}\right\}$ \\ Balai Penelitian dan Pengembangan Agama Makassar \\ Jl. AP. Pettarani No. 72 Makassar $1,2,3,4$
}

\begin{abstract}
This article talks about Sufi traditions synthesized into a local tradition, it is called barakong and taken from the manuscripts brought by the first qadhi Bantaeng, who was a kind of justice minister in the local kingdom. Barakong not only has a Sufism meaning but has also reproduced its meaning by users of its tradition as something that can bring blessings, as a prayer to avoid wickedness, and prophet history dissemination. This meaning shows a religious expression that is accommodating to local culture and is a characteristic of the Sufi culture that has spread throughout the archipelago since the beginning of Islam. The encounter with the Sufi Barakong tradition and the local a'burangga tradition shows the role of qadhi as a guardian of Islam that is friendly to local culture. Sufi tradition is identified as a religious characteristic known as Islamic culture.
\end{abstract}

Keywords: a'burangga, barakong, manuscript, Sufi poetry, local traditions

\section{Introduction}

The Chanting of Sufi poetry is actually an expression of a Sufi's joy in meeting God. However, the Bantaeng people use this Sufi poetry as an expression of joy in finding a mate. Barakong is a Sufi poem that is featured in the traditions of the a'burangga, the king's bride and the king's Bantaeng line until now. Sufi poetry is the work of Ibn Al-Farid from 1181 AD which contains love for God. Great Sufis like Ibn Al-Farid has a tradition expressed joy when he met God in the form of song lyrics [1]. A tradition of love expression adopted by the descendants of the king of Bantaeng in the world of encounters between the bride and groom. Namely by singing the Sufi barakong on the night of a'burangga, a tradition carried out to give blessings to the prospective bride and groom in preparation for the wedding the next day.

Adaptations of Islamic traditions in local traditions are often found in Nusantara society. In fact there is a tradition of the Arab Islamic world, practiced in full within Arab communities, such as dance samrah in Gorontalo [2]. Therefore, the maintenance of the barakong tradition in the Bantaeng community is an effort to combine local traditions and Arab traditions that are considered Islamic. Religion here to attract the sacred and absorbed in a tradition that can strengthen social cohesion. Although it may only apply in internal community [3]. The aspect of social cohesion in local traditions that absorbs religious 
traditions can guarantee harmony in a society that is predominantly Muslim. Even though the meaning of this tradition has shifted from its original meaning.

Studies on Ibn Al-Farid's poems have been widely carried out, particularly related to the themes of love to God related to Sufi themes about love for God [4] [5], [6]. His thoughts about love for God as summarized in diwan ibn al-Farid made him known as sultan al-asyiqin, the prince of love [7], [8], [9], Even the poems of Ibn Al-Farid often juxtaposed with the discussion of the poems of Ibn Arabi in the context of loving God [1], [10]. It seems that the study of poetry Ibn Al-Farid has been limited to the study of texts. So far, there has not been any discussion related to the barakong tradition which is claimed to only exist in Bantaeng. Namely the tradition of singing Ibn Al-Farid's love poems combined with regional language lyrics in a bridal ceremony. A cultural encounter spanning distance and time with different languages and cultures that produce different meanings.

Barakong Sufi poetry chants have long been carried out in Muslim countries such as Egypt, Tunisia, and Syria [11], [12], [13]. They are singers in the country which makes the Sufi poetry as songs with different musical arrangements. Each of these artists has a distinctive voice and tone and makes the barakong a part of the religious songs they carry. As did Syekh Yasin at-Tahami Bulbul Atas, who also sang the barakong poetry in the Arabic musical version. Barakong Sufi poetry singing is a family tradition that is carried out from generation to generation from their ancestors. Yasin at-Tahami then amplify the fun tradition of the Arabic poetry by studying Arabic Literature at the University of Al-Azhar. So that his soul in singing Sufi poetry is in tune with the reality of the meaning of the lyrics [14]. In contrast to the barakong sufi chanter community in Bantaeng, they do not come from the Arabic tradition and do not study Arabic which allows them to understand the reality of the meaning of these poems. But they inherit the singing hereditary with meanings that may be shifted from time to time. This is the focus of the discussion of this article with the following questions: 1) What is the history of the existence of the manuscripts and traditions of barakong poetry in Bantaeng? 2) What is the community's interpretation of the use of these poems 3) What is the religious character of the community based on the text of the text? The reality of the meaning of barakong poetry based on its lexical and grammatical meaning is Sufi poetry which tells about love for God. This meaning was reconstructed by the community using the barakong tradition in Bantaeng with symbolic efforts. They understand that Barakong comes from the word barakah, which in Arabic means blessing. So, by reading the barakong they hope to get blessings from Allah and His Prophet. The barakong tradition is also interpreted as an expression of gratitude to Allah, and is believed to be a prayer to avoid wickedness. These meanings and expectations are also logically matched with the aims and objectives of reading the barzanji as a series of the barakong tradition. As it is generally known in the people of South Sulawesi who practice the barzanji tradition as a prayer to avoid wickedness [15]. Apart from reproducing the meaning at the beginning of the barakong text, there are also meanings of the text that are relevant to the original meaning. Namely a poem that expresses the word tajalli (derived from Arabic which means disclosure) which is interpreted by the people of the barakong tradition as an effort to purify themselves to get closer to God. The process of achieving tajalli is even known as Sufi paths that are familiar to tarekat followers or fans of Sufism in Bantaeng. A religious practice that is identical with the Sufi culture as a legacy of the qadhi disseminator of Islam in Bantaeng.

\section{Literature Review}


The articles on Arabic Sufi poetry can be found in several forms: The first of which is mostly found from a linguistic aspect, such as studies in the form of sharia in the form of a brief explanation of the meaning of poetry in Ibn Al-Farid's collection of manuscripts. [16], [17], [18]. Second, there is also a study of the structure of the language is technically shows a high difficulty level. The forms of the style of language is often a study in learning the words to a student majoring in Arabic Language and Literature [19]. Third, the debate about the concept of loving God between Ibn Al-Farid and Ibn Arabi [1]. Fourth, the discussion of poetry Ibn Al-Farid is also used as a reference in the book of commentary ruhul Ma'ani: 30 pages 103 to explain the meaning of sabbihisma rabbik al-a'la. In this section, the author cites poems (called barakong): abarqun badaa min janibil gauri lami'-am irtafa'at an wajhi Layli al-baraqi ', explained that this sentence is a form istiarah (parable), the meaning of the word is meant to purify the Lord is not the meaning of synonym with the name of God. So that the word layli in this sentence does not mean God [20].

One of Ibn Al-Farid's syarah (brief explanation) diwan is Taiyyah Abdul Rahman Jami which is arranged in 352 pages, with a composition consisting of; opening about Ibn AlFarid as sultanul asyuiqin means the prince of love, biography of Ibn Al-Farid, his education journey, support, criticism and controversy of Ibn Al-Farid, poems from Ibn Al-Farid's poetry, expressions of the Ibn Al-Farid, and his brief explanation [21]. Another brief explanation was written by Muhammad Mustafa Hilmi with the title Ibn Al-Farid wal-hubb al-Ilahiy with a thickness of 514 pages. The main discussion of this book is the placement of Ibn Al-Farid's position as a prominent Sufi. The author also presents seven famous writers from the books of Ibn Al-Farid with their various approaches [22].

Reflection linguistic study results also revealed the presence of Sufi poetry as Sufi culture that formed following the activities and experiences of their quest to find the love of God [23]. Sufis have a habit of expressing their ideology in the form of literary works or works of art as was done by Ibn al-Arabi and Jalaluddin Rumi. [24]. Sufi expression through poetry, songs, music, dance and even showed an expression of delight in religion. Pleasure religious show religious character that is not stiff, and identified as moderates [25]. This moderate religious character which was then termed in this article as cultural Islamic character.

The practice of Sufi poetry sung in the local traditions of the Indonesian people has actually been going on for a long time. But there are not many articles about it. So far what can be traced is the tradition of dance asudati as the Acehnese Lhokseumawe people. This is a Sufistic dance accompanied by music and song lyrics [26]. As for the tradition of barakong poetry singing in Middle Eastern countries, so far no one has specifically studied it, or no study has been published on it. Therefore, this article focuses its study on the meaning of the Bantaeng community of the tradition of barakong Sufi poetry singing.

\section{Method}

This article is the result of a qualitative descriptive study carried out in the royal family in Bantaeng, South Sulawesi. A community that has a tradition of singing Sufi poetry known as barakong. This chant was subsequently transmitted from generation to generation and could only be performed within the royal family. Arabic Sufi poetry is mixed with local poems in the Ancient Region. The user from the community itself does not really understand the meaning of these poems. Therefore, this study uses a symbolic approach to find the 
meaning of barakong poetry by extracting data through interviews, observation, and text study.

In-depth interviews were conducted by barakong actors who were only in the community of descendants or relatives of the king of Bantaeng. Informational interviews through interviews with members of the general public were also conducted to find different data. Namely by tracing anyone who has experienced the situation from the barakong tradition and manuscripts. Furthermore, observations were made of the implementation of the barakong in the a'burangga event on August 27, 2020 at the house of a citizen of aristocratic descent. As for the study, the text was carried out to trace comparative sources of the barakong manuscripts which were mostly written in Arabic and English.

\section{Results}

\subsection{History of the Barakong Manuscript}

This barakong manuscript is the handwriting of qadhi Abdillah, the last qadhi of the Bantaeng kingdom. The manuscript in the form of a copy of a Sufi book was given to $\mathrm{Kr}$. Dode by qadhi Abdillah (died 2015.) He received the manuscript because he had a lineage with the qadhi, and he had the ability to continue the tradition of reading the text. The full and original form of the barakong manuscript was not found from the pile of kitab kuning left by the qadhi. According to the collector, the manuscript was first brought by Syekh Nur Baharuddin, namely the first qadhi in the Bantaeng kingdom who taught Islam to karaeng Majombea 1689. He was a messenger from Gowa known as Tajul Naqsyabandiyah, tu ttetea ri tompo'na jenneka, which means man walking on water (Andi Rakhmad AB, Interview 30/08/2020).

Syekh Nur Baharuddin, apart from being sent as a religious teacher for the king, he was also assigned to become a Bantaeng qadhi. Qadhi is the king's assistant, at the same level as the minister in charge of handling legal and judicial matters. The first thing that was introduced to the king was the rituals of worship which was then practiced en masse by holding the first Friday prayer with the king of Bantaeng on April 2, 1689. As a qadhi, Syekh Nur Baharuddin also carries out the government's mission in the field of religious affairs as well as supports to provide religious education to the community. This mission is supported by several sets of texts that have been transmitted from generation to generation. Namely the complete text of the Quran, barazanji, barakong and sikkiri Jummat (Andi Rakhmad AB, Interview 30/08/2020).

The inheritance of Syekh Nur Baharuddin's manuscript was carried out by means of copying and or physical submission of the manuscript. Manuscript copying is usually done through mangaji kitta 'by hand writing. So that someone who copies the manuscript is confirmed to be a direct disciple of the owner of the book he copied. The full manuscript is given to the next generation of qadhi tasks, namely people who replace qadhi who have ended their duties due to their death. The substitute for qadhi is usually chosen from the descendants of qadhi who were previously prepared by sending him to study religion in Mecca. If qadhi does not have children to replace him, then the selection of qadhi can be appointed by the king from among the ulama who are then brought closer by marriage with the king's daughter or relative (Muh. Nasir, Interview 01/09/2020).

Currently, not all legacy manuscripts or copy manuscripts are preserved intact. Some are missing, some are damaged by age and some are deliberately destroyed by certain parties. The manuscript that is still intact is the AL-Quran which is now stored in the Old Mosque of Taqwa Tompong Bantaeng. A copy of the barakong manuscript is kept by Andi Rakhmad 
along with the akhbarul Akhirah manuscript (tulqiyamah manuscript), sarassa manuscripts, and kitab kuning from Abdurrahman's qadhi (as stated in the inscription on his book: Abdurrahman imang Bantaeng) which is also obtained from qadhi Abdillah. The kitab kuning are: tafsir jalalain, sahih bukhari, I'anat ath-thalibin, and syamsul ma'arif al-kubra. The manuscript that was missing was the Sikkiri Jummat manuscript, which was the last time we encountered the tradition of reciting dhikr in recitation every Friday night at Balla Lompoa Bantaeng. The loss of Sikkiri Jummat was also exacerbated by the descendants of qadhi who did not know the family tree. So that the information known about Bantaeng qadhi has only a few names, namely; Syekh Nur Baharuddin, Imang Abd. Rahman, Ramli, Baharu, and Abdillah (Andi Rakhmad AB, Interview 06/09/2020).

Another source mentions the name Qadhi Pua Macoa Amin who was replaced by his son-in-law Abdillah, the last qadhi. Barakong manuscripts are also said to be not only centered on the Qadhi circles. But there is the name Guru Becce who also has a barakong manuscript. In adolescence, Nasir, who claims to be not from a royal family or not from the nobility, often witnesses the duet of barakong poetry chants performed by Guru Becce with her husband in bridal and circumcision events. Even when his siblings got married, the barakong recitation was also performed with gandrang accompaniment on a'burangga night. Unfortunately, Teacher Becce's manuscript is no longer physically found (Muh. Nasir, Interview 01/09/2020).

Barakong reading by singing Sufi poetry in the tradition of marriage and circumcision performed by the general public is different from the information given by $\mathrm{Kr}$. Dode. According to his experience, barakong reading is only done for certain groups. Namely, a special group of descendants of kings or nobles. If the offspring is not from the male side, then reading the barakong is not necessary. It was a tradition of the qadhi's legacy that he received the manuscript directly from the last qadhi. In connection with that, there have been descendants of kings who should have performed barakong recitations and did not do them. So, the person is reprimanded by the possession of spirits from his family members (Andi Rakhmad AB, Interview 09/09/2020). 
Table 1: Text Edition and Translation of the Barakong Manuscript

\begin{tabular}{|c|c|}
\hline $\begin{array}{l}\text { Barakong poetry in Arabic } \\
\text { Translated by Muh. Subair }\end{array}$ & $\begin{array}{l}\text { Barakong poetry in local language } \\
\text { Translated by Faisal Umar El-Chapra }\end{array}$ \\
\hline أبرقُ بدا من جانِبِ الغَور لامعُ & $\begin{array}{l}\text { Iyyatomminne bosiyya, rammang } \\
\text { massikambeyya }\end{array}$ \\
\hline $\begin{array}{l}\text { Terbitlah cahaya terang berkilau dari sisi } \\
\text { lembah }\end{array}$ & $\begin{array}{l}\text { Inilah hujan, awan yang bertautan } \\
\text { Here is the rain, the clouds that mesh }\end{array}$ \\
\hline أُجِ ارتفَعَتْ عن وجهِ ليلِى البر اقع & $\mathrm{Na}$ tangku cini a'rungan na a'rungiyya \\
\hline $\begin{array}{l}\text { Apakah itu terbit dari wajah Lailah yang } \\
\text { bersinar terang }\end{array}$ & $\begin{array}{l}\text { Dan saya tidak melihat jalan yang } \\
\text { dilaluinya } \\
\text { And I don't see the road he's on }\end{array}$ \\
\hline نعم اسفرت ليلى فصار بوجهها & $\begin{array}{l}\text { Iyyatomminne bosiyya, rammang } \\
\text { massikambeyya }\end{array}$ \\
\hline $\begin{array}{l}\text { Duhai iya, pancaran sinar cahaya Lailah } \\
\text { memperlihatkan wajahnya }\end{array}$ & $\begin{array}{l}\text { Inilah hujan, awan yang bertautan } \\
\text { Here is the rain, the clouds that mesh }\end{array}$ \\
\hline نهار ا به نور المحاسن ساطع & $\begin{array}{l}\mathrm{Na} \text { tangku cini } \text { Kampongna } \mathrm{Na} \\
\text { Pantamakkia }\end{array}$ \\
\hline $\begin{array}{l}\text { Hari demi hari keindahan cahaya itu uterus } \\
\text { bersinar }\end{array}$ & $\begin{array}{l}\text { Dan aku tak melihat kampung yang } \\
\text { dimasukinya }\end{array}$ \\
\hline $\begin{array}{l}\text { Day after day the beauty of the light was utterly } \\
\text { shining }\end{array}$ & And I didn't see the village he entered \\
\hline ولما تجلت للقلوب تزاحـــــت & $\begin{array}{l}\text { Iyyatomminne } \\
\text { massikambeyya }\end{array}$ \\
\hline $\begin{array}{l}\text { Seketika membuat hari bergetar dan } \\
\text { bergemuruh } \\
\text { Instantly made the day vibrate and rumble }\end{array}$ & $\begin{array}{l}\text { Inilah hujan, awan yang bertautan } \\
\text { Here is the rain, the clouds that mesh }\end{array}$ \\
\hline
\end{tabular}

Table 2: Local Text Edition in the Barakong Manuscript

\begin{tabular}{|c|l|l|}
\hline Aksara Serang & \multicolumn{1}{|c|}{ Lontara } & \multicolumn{1}{c|}{ Transliterasi } \\
\hline تمممن تغ ر تجلي & Tumam Menteng ri Tajalli & Tumam Menteng ri Tajalli \\
\hline
\end{tabular}




\begin{tabular}{|c|c|c|}
\hline تن رنك سنجلال & Tuni Rangka sin Jalalaa & Tuni Rangka sin Jalalaa \\
\hline تن كمبول & Tuni kim Bolong & Tuni kim Bolong \\
\hline سيغر تكلفكن & Singara Ta Kalapak Kang & Singara Ta Kalapak Kang \\
\hline كنت ء بايغ رجين & Kuntu I Bayang Ri Jennee & Kuntu I Bayang Ri Jennee \\
\hline تنتنغن ر جرمغ & Tontongan ri Carammeng & Tontongan ri Carammeng \\
\hline ليو ليون نتلثا & Leyo' Leyo' Na Tallasa & Leyo’ Leyo' Na Tallasa \\
\hline 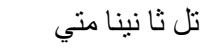 & Tallasa Tinm Mateyyaa & Tallasa Tinm Mateyyaa \\
\hline
\end{tabular}

In this manuscript which is adapted from the original book, it appears that there are differences from the manuscript copies found in Bantaeng. There are two poems are not found in manuscript copies, namely:

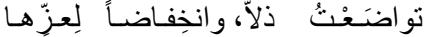

With him I am humiliated and humbled in all glory

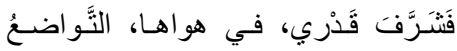

With it I respect all my destinies in the Desire of humility.

There are also words that are not appropriate, for example the word naarun should sound nahaarun with a different meaning.

\subsection{The Origin of Barakong}

This barakong poem is a fragment of the poetry of the diwan Ibn Al-Farid, who was famous as a Sufi poet from the Abbasid era [22]. Ibn Al-Farid's work containing Barakong's poetry is found in Ibn Al-Farid's Diwan, with the following description:

Written by: Ibn Al-Farid

Subject: Poetry

Binding type: folder art

Paper type: White

Pages: 222

Print Year: 2011

Edition: 3

Size: 17 x $24 \mathrm{~cm}$

ISIN: 9789953134109

Dollar Price: 5.75 - Site Price: \$ 3.74 (excluding service and shipping) for hard copy

Code: 520191

Publisher: Dar Sader - Beirut - Lebanon

Paper copies: Available on site, Al-Azhar Library, Nasr City Library, Bibliotheca Alexandrina [27]

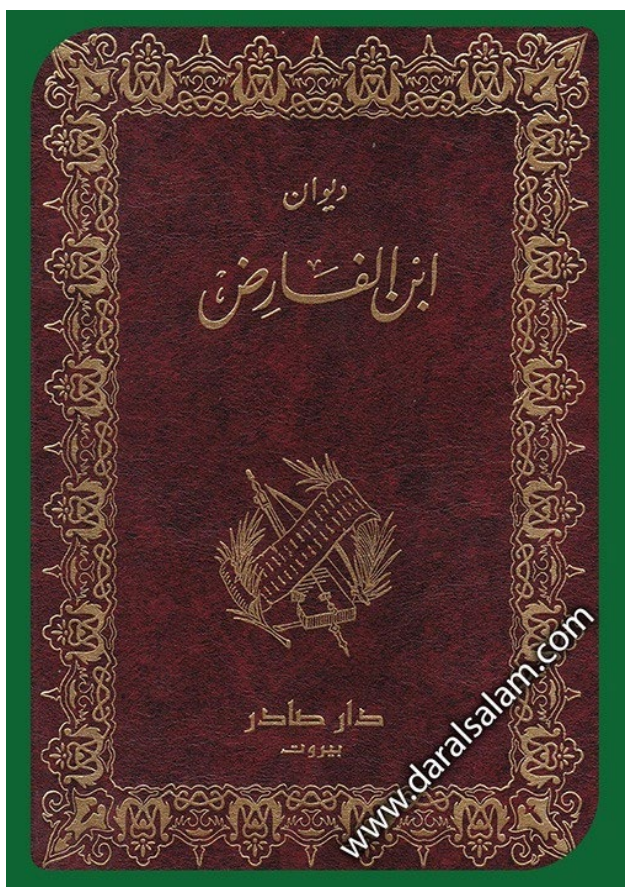


The book of Diwan Ibn al-Farid has been translated into English by Paul Smith under the title Diwan of Ibn Al-Farid, an Egyptian poet (1181-1235 AD). He is considered a master of Islamic mystical (Sufi) poetry in Arabic. He was not only a poet but also the perfect teacher for the God-conscious soul. His journey to union with God, he said in the longest qasida in Arabic (as many as 761 stanzas). His most famous poem is The Mystic's Progress. Another well-known poem is Poetry about Wine which is often seen as a prologue to The Mystic's Progress. Although these lengthy poems have previously been translated into English, this is the first time the edition in the poem truly feels as a qasida of modern English that is clear, concise and easy to understand [27].

The word barakong is taken from the beginning of the poetry which reads abarqun bada min janibil ghauri lami ', which means "a bright light shine from the side of the valley". The sparkle of light is assumed by the name Lailah, a name that represents the beauty of the face of the owner with the beauty that increases day by day. An atmosphere that builds a longing for a lover with a longing that humbles the lover himself. When the lover is bowed low with all his weaknesses, the awareness of the beauty and greatness of the loved one is heightened, only the hope of his affection gives him the hope of surviving his love. The parable of the beauty set out in these poems is said to be wasilah (intermediate) to get closer to God. This sentence is not at all as a pronoun for the Most Holy One.

\subsection{Barakong procession}

Barakong is performed at a'burangga event in the wedding custom of the Bantaeng community. A'burangga is often referred to as akkorontigi in the Makassar Tribe community and is also referred to in the Bugis Tribe as mappaccing. The meanings of the three terms both refer to efforts to cleanse oneself or purify oneself physically and mentally. The purification effort is then marked by giving a prayer of blessing using symbols that are considered sacred. Giving blessing to the prospective bride and groom is given by family leaders, traditional leaders, community leaders, religious leaders (qadhi or imang), and especially from both parents. When the blessing begins, the barakong singing begins, followed by the gandrang tallua/ tunrung tallua (traditional drum).

A'burangga is done at night in preparation for the wedding ceremony which will be held the next day. The large number of events that evening gave rise to many terms such as bangngi annappungi, an event prepared for a relative or close relative of the bride and groom to apply powder to her body. There is also a appatamma event, namely the Quran graduation ceremony led by the tutor, Imang or qadhi. Then proceed with the reading of barazanji in Arabic and the local language of Bantaeng with typical selawatan songs. The climax event was held after a short break from reading barazanji. Qadhi, imang, guru or currently by ustaz the leader of the barazanji team has an important role to open the a'burangga event accompanied by the singing of the barakong poetry and tunrung tallua (traditional drum).

The chanting of the barakong stanza combined from Ibn Al-Farid's stanza with the Bantaeng area seems to work in two ways. First, by singing it together in a team of 5 to 10 people, according to the size of the team members in the barazanji reading. Second, we also found the singing of barakong poems with a duet version that emphasized the importance of exploring the beauty of sound. This second method has not been found since the death of Guru Becce, who in the 1980s often performed duets with her husband in performing the barakong. Currently, the remaining barakong appearances are in the form of a team that prioritizes cohesiveness and harmony of sound.

Barakong as a religious tradition is also performed with local traditions with special food offerings. Various kinds of special foods must also be equipped with burning incense or 
fragrant wood. In the past, the presence of traditional food was arranged with different uses according to the intention of the person serving it. According to Karaeng Dode's statement, the provision of food offerings was carried out based on the habit of serving food in sacred places. When qadhi came to teach Islam in Bantaeng, the habit of feeding in the forest, river, sea and trees was replaced by only providing food at home.

Initially, the intention of serving food at the house was still often referred to as its designation, for example for parents who had died. But now, these food offerings are no longer accompanied by such intentions. Even food offerings seem more concerned with aspects of appropriateness and beauty of their appearance. The variety of traditional food served is no longer with a motive to be offered to anything other than the attendees who come to the event which is synonymous with a banquet.

Barakong poetry performances in terms of time can be found in three places. First, in the appassunna tradition, circumcision. A tradition that also requires the existence of a tunrung tallua (three drum) for the royal family. Second, the performance of the barakong in the a'burangga tradition, which means the evening of blessing the bride and groom. In this tradition, the attendance requirement of tunrung tallua is required for three days, which then becomes part of the barakong poetry performance. Third, performances for the purposes of cultural festivals and the implementation of regional celebrations. The performance of the barakong as a tourist attraction has been done at Balla Lompoa Bantaeng which was specially prepared to attract the attention of the public and tourism lovers.[28]. In addition, the performance of the barakong poem was also initiated by the South Sulawesi Language Development Agency in an effort to inventory regional literature in Bantaeng. This event was carried out by involving the community from various elements, and was attended by local governments representing the Regent (Bupati), Camat and Kepala Desa [28].

The Tune Tunrung Tallua drum has a beating philosophy which is in line with the meaning of the barakong poem. For example, a drum beat twice, three times and seven times is interpreted as a symbol of practicing Sufi teachings. As known in the phrase "Dua tamssaraung Tallu Tamallesang”, namely two that are never separated and three which are always together. The seven are interpreted as the peak of human servitude to God which is expressed in prostration, where at the time of prostration a man declares servitude to God by surrendering seven limbs to worship prostration by pressing them on the ground. The seven limbs in question are the legs, knees, hands, and face.

\subsection{The meaning of Barakong}

The meaning of the barakong text is not inherited properly and is in line with the original manuscript, which is also unknown. The problem of missing the original barakong manuscript is quite natural because of the long distance it has had from its first author. Shaykh Nur Baharuddin copied the manuscript from Mecca about 360 years ago. It can be assumed that the manuscript has been damaged with age or lost because of a disaster. the condition of the disappearance of the original manuscript was followed by the loss of the original meaning of barakong which means shining light in the context of Sufi understanding. Furthermore, the message conveyed from the barakong poem actually emphasizes the expression of Sufi happiness when experiencing an encounter with God. But for the people who use the barakong singing tradition in Bantaeng, the barakong poem has a different meaning.

The barakong user community develops several new meanings that develop by understanding that barakong comes from the word barakat in Arabic which means barakka in the regional language, namely blessing. So that people who carry out barakong are expected to get blessings from God Almighty. This meaning is the result of the presumption of the 
sacredness of Arabic texts which are always identified with the supernatural powers of Islam. So that the names of the Prophet's companions were often interpreted as baraka, which was then used in recitation or incantations for various purposes. Like the use of the name Abu Bakr in a spell to treat an illness, which usually ends with the sentence "barakka laa ilaaha illallaah kun fa yakun". So it is very easy for people to bring the word barakong in the meaning of blessing because it sounds so close to the sound of the word barakat or blessing.

Barakong is also interpreted as an expression of gratitude to God for all the blessings He bestows on humans. The expression of gratitude through barakong refers to its use in the a'burangga and appassunna traditions, where the two traditions are symbols of the happiness of the people who hold them. The tradition of a'burangga is synonymous with crowds, joy and joy over the big events that will occur between the two human children who will build a new life. Likewise, the tradition of assunna is a happy day for a family for the gift of a boy who is getting pubescent, so that it is celebrated in a moment of circumcision which is coupled with a pledge of two sentences syahadah or often called announcing the child's Islam. So barakong has an element of entertainment and can be called a joyful song.

The placement of the tradition of singing the barakong poem in a joyful atmosphere is the opposite of the tradition of akhbarul Akhirah which is always sung in an atmosphere of mourning. This shows the community's efforts to build a balance when facing happy days and days of condolence to face both of them through the tradition of singing. So the expression of condolences found in the tradition of singing akhbarul Akhirah (tulqiyamah) is a symbol of the sadness of the community who uses it. The two of them show differences with the barazanji function which appears to be multi-porpouse which is usually used in dealing with various moments from birth to death.

Another meaning of the barakong stanza is emphasized by the form of its implementation where the performance is placed with the reading of barazaji. When popular barazanji is understood in terms of the stories of the prophet Muhammad, then barakong is interpreted as a text which also contains the story of the prophet. The multi-function barazanji which summarizes various purposes either as an expression of gratitude or to avoid wickedness, automatically also intersects with the objectives of the barakong. These goals also converged when barazanji was performing with barakongs. In addition, the meaning of barakong as a hope to avoid wickedness also supports its interpretation as a blessing. Whereas by bestowing blessings on those who carry out the barakong tradition, at the same time they are also prevented from any wickedness or disaster.

The language and character of the meaning of the barakong which contain Islamic values are symbols that attract and grab people's attention. The Arabic texts of the barakong stanza sung at night in the crowd a'burangga and in the crowd appassunna are used as the spread of Islam. So that there are always listeners who respond with the words of Allahu Akbar, masya Allah and say the prophet's salawat. Likewise, with the hopes of the team that brought the barakong bait, always considering the texts they sang as an expression of happiness and joy in religion. Through the singing, there is also a message of peace through the song tones and the beautiful drum sound arrangement.

The meaning of the barakong poem which represents religious symbols also shows an adjustment to local traditions. The conditions for carrying out the barakong chant are complemented by a variety of typical Bantaeng foods that must be served. Kelepon or umba$u m b a$ is one of the special foods that must be presented with a symbolic meaning. Umba-umba when submerged in a pan while cooking, it quickly gets up and floats. This condition is expected to apply to the prospective bride so that when she drowns in facing domestic trials, she can immediately get up to solve her problem. Likewise, with the presence of other foods, 
such as bananas, pumpkin, coconut and brown sugar. All of them embed messages that are usually retained at traditional events to remind attendees of the consequences of having the meal. It is the tradition of serving typical food that is collaborated with the tradition of barakong singing which is the meeting point between culture and religion.

At the end of the barakong poem, there is the word tajalli which is still well understood by traditional actors. That the expression tajalli implies the holy journey of humans to meet God. The tajalli process which begins with self-emptying must always be followed by filling oneself with commendable morals as a condition for obtaining knowledge. This understanding is obtained from the teachings of Sufism, whose practice is still strong for leaders of the barakong tradition. According to him, self-emptying is primarily self-cleansing starting with correct istinja or taharah. This part of the tajalli poem then reconnects the meaning of the barakong from its original meaning as a Sufi poem.

\subsection{Discussion}

The expression of feeling happy when meeting God as stated in the barakong poetry is material that is used as a song in the a'bburangga tradition. Barakong poetry represents Islamic tradition while a'burangga represents local traditions that are brought together on stage to give blessings to the bride and groom. This condition is in line with the phrase drawn from the drum that accompanies barakaong, "the two were inseparable and were always in line three" is a picture of meeting a mystic union with God who called the summit (climax) Sufism or syatahat. When a Sufi experiences syatahat, it is what gives birth to poems that describe the beauty and longing for this union. The strength of these poems lies in their compelling sentences, and their ability to create the tone and flow of the song. Furthermore, the singing has the potential to move the body which is then called the Sufi dance.

So, barakong is an expression of Sufi happiness over meeting God. This is what makes this poem have a magical power that is entertaining and fun for those who listen to it. That is what prompted the first qadhi of Bantaeng to introduce barakong poetry on the night of the bride and groom's happiness, as a miniature of the expression of happiness for loving God that can be learned from the expression of a person's meeting with his beloved lover. If the meeting with fellow humans who love each other can produce high happiness. So what about meeting God who is truly more loved than anything else in this world.

The meaning of the barakong song in the a'burangga tradition has a consequence of local Islamic historical facts and the religious characteristics of the Bantaeng community. This can be observed in the following statement:

The presence of the barakong in Bantaeng was first brought by qadhi who was also the first qadhi in the Bantaeng kingdom. This fact re-raises the position of qadhi which changed the royal structure from customary domination to one that was reduced by the presence of the syara structure. The position of syara which is parallel to the adat 12 (customary institutions, some kind of royal council) Bantaeng is emphasized by the approach of raising qadhi which is culturally selected from the royal family.

That is why the first qadhi of a Gowa envoy named Syekh Nur Baharuddin was later married off to the royal family, as a way to bring him closer to the royal circle. Thus, the selection of qadhi always considers aspects of kinship with the king with the main requirement of mastery of religious knowledge. If the prospective qadhi replacement from the royal family has less mastery of religious knowledge, then the selection of qadhi will be taken from among the ulama who are then brought closer to the royal family through marriage ties. Family approach in the qadhi appointment is a strategy for strengthening the position of qadi avoid getting pressure from the adat 12 (royal council). 
The balance of the position of adat and syara institutions has an impact on the existence of negotiations in the implementation of local traditions so that they are adjusted to religious traditions. The presence of qadhi in the adjustment process is very vital and strategic, because the developing tradition cannot be carried out without the presence and approval of qadhi as the competent state official. The role of qadhi can also be socialized through recitation activities, lectures and Friday sermons which are also his main duties. Apart from that, qadhi also has an extension for policy sustainability at the regional or village level. One of the relics of qadhi that has been preserved from generation to generation is a form of recitation of the kitab kuning which has been applied in Islamic boarding schools to this day. The position of the kitab kuning recitation is a characteristic feature of strengthening cultural Islam, or Islam that is friendly to local culture, as seen in the tradition of barakong singing.

Syara institutionalization side by side with customary institutions is a pattern that occurs in all areas of the archipelago kingdom. So that the slogan appeared "adat bersendikan syara and syara berendikan adat". This emphasizes the religious face of the Bantaeng people that is unique to the archipelago, which emphasizes its practice in a cultural Islamic style. Namely Islam which does not emphasize its goal of political power. But it is more oriented towards developing socio-cultural aspects through religious education that is culturally friendly and includes all social, economic, health, environmental and peaceful preaching aspects [29].

This cultural Islamic style seemed relevant to the function of qadhi in royal government. The position of qadhi is even seen as contradicting the political Islam fighters who always want the establishment of an Islamic state in the form of a caliphate. Where the presence of qadhi is very far from changing the royal system into an Islamic caliphate system. Qadhi is busier providing assistance in the community through recitation activities and the implementation of religious traditions that are familiar with local culture. Like the tradition of Barakong Sufi singing combined with regional language poetry.

\section{Conclusion}

A piece of heaven stranded in Bantaeng through a piece of Sufi poetry that contains the expression of the Sufi's happiness when he meets God (the peak of attainment is called syatahat). A situation of syatahat whose enjoyment is equivalent to that of an ordinary human being is guaranteed heaven. The Sufi poetry comes from the manuscript text that was brought by the first qadhi of Sheikh Nur Baharuddin, a messenger from the Kingdom of Gowa in 1989 AD. The physical condition of the manuscript obtained is in the form of a copy that is no longer the original of the first author. The original manuscripts are thought to have been lost or damaged with age. Based on literature search, it was found that the barakong poetry manuscript was the work of Ibn Al-Farid from 1811 AD. A Sufi poet known as sultanul 'asyiqin, the prince of love.

Barakong poetry lexically means the sparkle of light that reflects the beauty experienced by a Sufi when syatahat. But for users of the barakong tradition in Bantaeng, barakong is defined as a blessing, or the hope of blessing from God. This interpretation is also accompanied by adjustments to the barazanji tradition which is interpreted as an expression of gratitude, avoiding wickedness, and broadcasting Islam. Even though the initial sentence of the barakong poem is interpreted differently from the original meaning, it turns out that in the 
final sentence of the poem, a meaning that is relevant to the original meaning appears. That is the tajalli sentence which is interpreted as the union of man and his God.

The existence of manuscripts and the tradition of barakong poetry singing which is staged with the a'burangga tradition shows the diversity of the Bantaeng people who are friendly to the local culture. This is the result of guidance from ulama whose knowledge is obtained directly from Mecca. The ulama then took the position as the first qadhi of the Bantaeng kingdom who built the typical Islamic civilization of the archipelago. A form of diversity which is termed cultural Islam.

The Sufi tradition with barakong singing in a'burangga in the Bantaeng community was popularized and built by qadhi as a tradition that is integrated with local traditions. This shows the central role of qadhi which is still culturally needed by the Bantaeng community as guardians of culturally sensitive religious traditions and has the potential to maintain harmony in society. Therefore, it is recommended to the authorities to revive the qadhi structure within the framework of a kingdom which is also culturally preserved. 


\section{References}

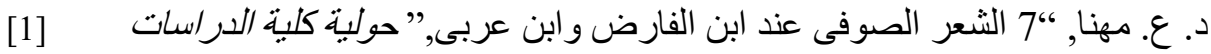

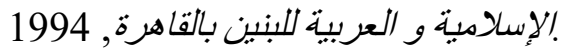

[2] A. Ibrahim, Zulkipli, and I. Niaga, "Tradisi Samrah Pada Pesta Pernikahan Oleh Keturunan Arab di Kelurahan Limba B Kecamatan Kota Selatan,” 2014.

[3] T. Abdullah, "Di Sekitar Masalah Agama dan Kohesi Sosial: Pengalaman dan Tantangan," J. Masy. dan Budaya, 2009.

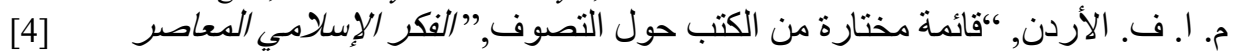

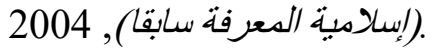

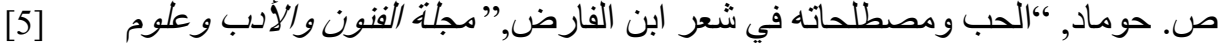

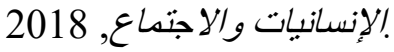

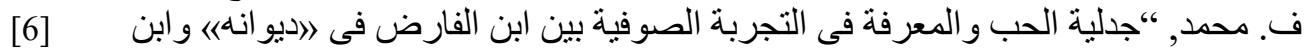

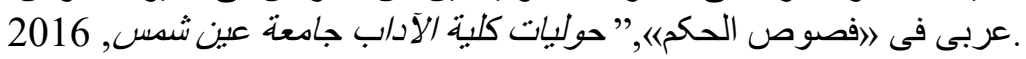

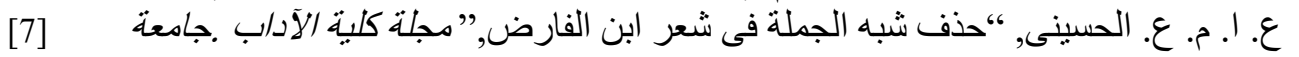
بورسعبي, 2016

[8] I. Al-Kaf, "Pemikiran Sufistik Syaikh Umar ibn Fa $>$ ridh dalam Di $>$ wa $>n$ Ibn alFa>ridh," Intizar, 2014.

[9 The Rhetoric of Counterpoint and Alliteration in the Minor Taa'iyah Poem of Ibn Al-Farid," Dirasat Hum. Soc. Sci., 2016.

و. مسيلي, “لغة الخطاب الأنثوي وتجلياته في الثعر الصوفي: قراءة في المنظومة [10]

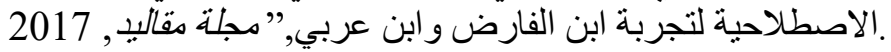

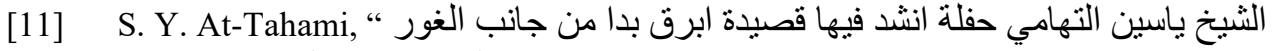
(Online]. Available: https://www.youtube.com/watch?v=idKBhuIrVjc\&t=30s. [Accessed: 13-Aug-2020].

[12] L. Bushnaq, "لطفي بوشناق - تواضعت ذلا/Walak Sy, 2013. [Online]. Available: https://www.youtube.com/watch?v=X9FVMGiFQME. [Accessed: 13-Aug-2020].

[13] S. Arshid, “ابرق بدا من جانب الغور - سيد ارشيد,”دليل العادحين الإنشادي//Dalel Almadeheen 2017 , . [Online]. Available: https://www.youtube.com/watch?v=13FHtERoxc4\&t=397s. [Accessed: 13-Aug2020].

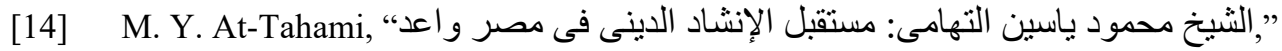

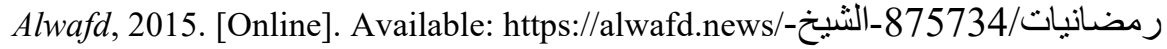
[Accessed: 13-Aug-2020].

[15] A. R. dkk Syam, "Tradisi Barzanji dalam Persepsi Masyarakat Kabupaten Bone," J. Diskurs. Islam, vol. 04 No. 02, 2016.

[16] M. M. Nasiruddin, Syarah Diwan Ibn Al-Farid Wafat 632 H. Libanon: Dar el-Kutub al-Ilmiyah, 1971.

[17] D. Al-Juawaidi, Diwan Ibn Al-Farid. Mesir: al-Maktabah al-Ashariy, 2008.

[18] D. bin M. bin M. Al-Qaisari, Syarah Taiyyah Ibn Al-Farid Al-Kubra. Libanon: Dar Al-Kutub Al-Ilmiyah Linnasyar Wat-Tauzi', 2004.

ط. زيناي, “التشاكل و التباين في التائية الكبرى لابن الفارض,” مجلة آفاق علمية, 2017 [19 
[20] S. S. M. Al-Alusi, Tafsir Juz Amma Ruhul Ma'ani. Libanon: Dar el-Kutub al-Ilmiyah, 1971.

[21] A. Jamiy, Tã 'iyya-yi 'Abd al-Rahmmān-i Jāmī: Tarjuma-yi Tā' iyya-yi Ibn-i Fārị̣ bih ... - Ibn al-Fārid. Teheran, 2019.

[22] M. M. Hilmy, Ibn Al-Farid Wal-Hubb Al-Ilahiy, Cetakan II. Mesir: Dar Al-Kutub AlMisriyah, 2019.

[23] A. Kholil, “KEARIFAN RITUAL DAN SOSIAL SYAIR-SYAIR SUFI,” Ling. J. Ilmu Bhs. dan Sastra, 2011.

[24] J. H. Shannon, "Suficized musics of Syria at the intersection of heritage and the war on terror; or 'a rumi with a view,", in Muslim Rap, Halal Soaps, and Revolutionary Theater: Artistic Developments in The Muslim World, 2011.

[25] A. Kristina, "Tari Sufi dan Penguatan Pemahaman Keagamaan Moderat Kaum Muda Muslim (Studi Kasus Tari Sufi Karanganyar, Jawa Tengah)," Sos. Budaya, 2019.

[26] K. Fazal, "Tradisi Tari Seudati Masyarakat Kota Lhokseumawe Aceh: (Analisis Epistemologi Islam Gerakan Dan Syair), Universitas Islam Negeri Sumatera Utara, 2017.

[27] Ibn Al-Farid, "Diwan Ibn Al-Farid," Dar As-Salam, 1983. [Online]. Available: https://aralsalam.com/ar/BookDetails/index?BookCode $=520191 \&$ Code $=1$. [Accessed: 06-Sep-2020].

[28] Ambae, "Puluhan Anak Bantaeng Pelajari Budaya Barakong," kla.id., 2019. [Online]. Available: https://www.kla.id/puluhan-anak-bantaeng-pelajari-budaya-barakong/. [Accessed: 08-Sep-2020].

[29] A. Azra, "Revisitasi Islam Politik dan Islam Kultural di Indonesia," Indo-Islamika, 2012.

\section{ABOUT THE AUTHOR}

Muh. Subair, is a researcher at the Makassar Research and Development Center for Religion in the fields of Literature, Religious Treasures and Organization Management. Research results that have been published are;

1. Internalizing Kalosara's Value in A Traditional Dance 'Lulo', Kendari, Southeast Sulawesi, 2017.

2. Tanduale: Rewarding Religious Education in The Ethnic Bugis and Moronene Brotherhood Agreement in South Sulawesi Bombana. Research Article in Proceedings of the First International Conference on Religion and Education 2019, INCRE, October 8 - 10, 2019, Bintaro, Indonesia.

3. A portrait of religious education in the indonesia-malaysia boder area (Case of Sungai Limau Village, central Sebatik District, Nunukan Regency, North Kalimantan) 2020. 